熊谷 隆秀* - 山田 英介・稲垣 愼二 - 高倉 剛 - 曽根 一祐

\title{
Study on Applications of Related Substance of Fullerenes Preparation and Properties of Related Substance of Fullerenes / SBS composites
}

Takahide KUMAGAI ${ }^{1}$, Eisuke YAMADA ${ }^{2}$, Shinji INAGAKI ${ }^{2}$, Tsuyoshi TAKAKURA ${ }^{3}$ and Kazuhiro SONE ${ }^{4},{ }^{1}{ }^{*}$; Aichi Institute of Technology, Graduate School of Engineering, Department of Applied Chemistry, ${ }^{2}$; Aichi Institute of Technology, Department of Applied Chemistry, 1247 Yachigusa Yakusa-cho, Toyota-shi, Aichi 470-0392, Japan, ${ }^{3}$; Mitsubishi Chemical Corporation, Kurosaki Plant 1-1 Shiroishi, Kurosaki, Yahatanishi-ku, Kitakyushu, 806-0004, Japan, 4; NITTO KAKO, Technical Development Center, 1-3, 6-chome, Ichinomiya, Samukawa-machi, Kanagawa 253-0111, Japan)

Fullerenes are the carbon materials that only 60 or more carbon atoms are covalently bounded. Since such greatly unique materials were discovered, many researches of fullerenes have been carried out. On the other hand, the unique carbon soot (CS) is yielded at production of fullerene, but it is not really investigated. However, we think that the application of CS is extremely important from the perspective of fullerene research and of market expansion. In this study, we prepared the composites by adding CS to styrene block copolymer (SBC), and then investigated the additional effect by measuring dynamic mechanical analysis (DMA), differential scanning calorimetry (DSC) and tensile properties. It was found that tensile modulus and heat-aging resistance of the SBC improved by adding CS.

(Received on November 4, 2008)

(Accepted on June 26, 2009)

Key Words : Styrene Block Copolymer, Fullerene, Nano Carbon Material, Composite, Viscoelastic Behavior

\section{1. 緒言}

フラーレンとは，60個 $\left(\mathrm{C}_{60}\right)$ ，もしくはそれ以上の，安 定して存在し得る個数 $\left(\mathrm{C}_{70}, \mathrm{C}_{76}, \mathrm{C}_{78}\right.$ 等 $)$ の炭素原子のみ で構成される炭素の安定相であり, 閉殸球状構造の炭素分 子の総称である. フラーレンの炭素原子の結合は, すべて $\mathrm{sp}^{2}$ 混成軌道であり, 五員環および六員環のみから成る. また，フラーレンは図形的観点から，五員環は必ず 12 個 含まれるというオイラーの多面体に関する定理と 12 個の 五員環は隣接しないという孤立五員環則 (Isolated Pentagon Rule，IPR)に束縛を受けて構造が決定する ${ }^{1)}$.このよ うに興味深い物質が，1985年にH.W.Kroto，R.E.Smallyら によって発見されて以来 ${ }^{2)}$, その研究に関する報告数は相 当量に至っている3 ${ }^{3-6)}$.

\footnotetext{
$1 *, 2$ 愛知工業大学

（テ 470-0392 豊田市八草町八千草 1247）

3 三菱化学株式会社 黒崎事業所

（T 806-0004 北九州市八幡西区黒崎城石 1-1）

${ }^{4}$ 日東化工株式会社 技術開発センター

(₹ 253-0111 神奈川県高座郡寒川町一之宮 6-1-3)
}

一方，フラーレンは製造法や製造効率が格段に進歩して きた．黑鉛を蒸発させてフラーレンを得るアーク法から， 炭化水素類を低圧層流炎として $1800{ }^{\circ} \mathrm{C}$ で燃焼する燃焼法 への転向と，その大量生産技術の確立 ${ }^{7)}$ が存在する。し かし，この方法でフラーレン類を工業的に製造する際，国 内生産に扔いて最も効率の良い燃焼法に扔いても, 炭素の 収率を上げるとフラーレンの選択率が下がり，フラーレン を溶媒で抽出した後に，未抽出成分として多くの炭素化合 物が回収される.フラーレンを工業材料として組み入れた 製品を市場で見かける中 ${ }^{8)}$ ，この未抽出成分に関する使用 用途の開拓および研究がほとんどなされておらず，このこ とはいずれ，フラーレンにかかわる産業ならびに市場に多 大な影響を与えることが推察される。このことから，フラ ーレンの市場展開を進めるためにもフラーレン製造時に生 じる未抽出分の有効活用法の確立もまた必要不可欠である と考えられる。

実際にゴム工業では, 同じ無機系炭素化合物であるカー ボンブラックが補強剤として用いられており, 未抽出分も 同様に配合検討がなされているようであるが，現状では公 
表されていない.

著者らは，これまでに省エネルギー，省資源化の点から 注目されている熱可塑性エラストマー(TPE)の改質およ び相構造と物性の関係を研究してきている。 そこで，本報 ではTPEとして最も一般的で, ゴム弾性に優れるスチレ ン系 TPE $(\mathrm{SBC})$ をマリクスポリマーに用いて，フラー レン製造時の未抽出成分とのコンポジットを調製し，得ら れたコンポジットの諸物性を測定，解析し，未抽出成分の 有効利用の可能性について検討を行った.

\section{2. 実}

験

\section{1 材 料}

マトリクスポリマーとして，ポリスチレン-block-ポリブ タジエン-block-ポリスチレンコポリマー (SBS と略記, JSR (怢製 TR2787, $M_{\mathrm{W}} ; 120 \times 10^{3}$ ，スチレン含量； $30 \mathrm{wt} \%$ ) を用いた。分散相として，フラーレン製造時の未抽出成分 (CS と略記，フロンティアカーボン侏製 nanom black，比 表面積 $50 \sim 100 \mathrm{~m}^{2} / \mathrm{g}$, 組成物中の比重 1.59）をそのまま用 いた．CSは，燃焼法で得られるフラーレン類を含む煤か らフラーレン類を溶媒抽出した未抽出成分であり，フラー レン類似構造を多く含む成分である．Figure 1に，溶媒抽 出可能なフラーレン類 (上図) 打よびCSに含まれると予想 される溶媒抽出不可能なフラーレン類の構造の一例 (下図) を示す.

また，比較対照としてカーボンブラック $(\mathrm{CB}$ と略記，東 海カーボン怢製 シースト 600 , 算術平均粒子径 $23 \mathrm{~nm}$, 比 表面積 $106 \mathrm{~m}^{2} / \mathrm{g}$, 組成物中の比重 1.58 )をそのまま用いた.

\section{2 コンポジットの調製}

コンポジットの調製は，6亿ンチオープンロールを用い， 室温，ロール間隙 $1 \mathrm{~mm}$ で，SBS20 $\mathrm{g}$ に対してCSまたは $\mathrm{CB} 0$ から $30 \mathrm{phr}$ の所定量となるよう混練した.フフラ 一混練後, 間隔を $3 \mathrm{~mm}$ として通してコンポジットを得た.

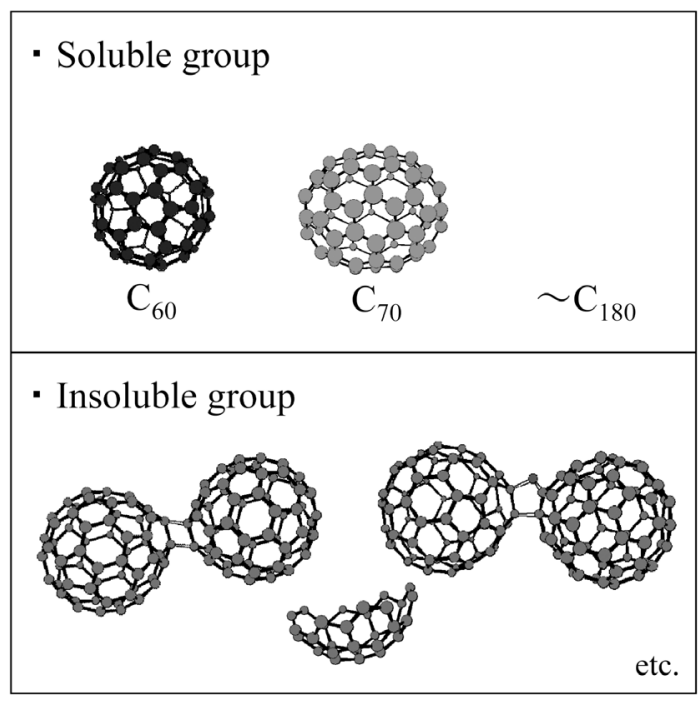

Figure 1 Chemical structure of fullerenes.
調製したコンポジットを $120{ }^{\circ} \mathrm{C} ， 150 \mathrm{~kg} / \mathrm{cm}^{2} ， 30$ 分間の 条件でシート状にプレス成型したものを測定用試料とし た．本報中の試料名は，例えばSBSにCSを $10 \mathrm{phr}$ 添加し た試料は, CS10 と略記する。

\section{3 物性測定}

\subsubsection{CSの表面観察}

測定用真鍮セルに固定剂を塗付し，CSをその上から散 布して固定した後，24 時間真空状態で静置して観察試料 を準備した。電界放射型走查電子顕微鏡 (FE-SEM，日本 電子(侏製 JSM-6335F) を用い, 加速電圧 $5.0 \mathrm{kV}$ の条件で観 察を行った。

\subsection{2 引張試験}

厚さ $1 \mathrm{~mm}$ のシートを 3 号ダンベル型で打ち抜き, 引張 試験機(オリエンテック侏)製 RTA-100)を使用し，室温下， 引張速度 $100 \mathrm{~mm} / \mathrm{min}$ の条件で測定を行った。

\subsection{3 示差走査熱量測定}

示差走査熱量計 (理化学電気(株)製 Thermo plus DSC8230) を用い，温度範囲 - $150 \sim 300{ }^{\circ} \mathrm{C}$, 昇温速度 5 ${ }^{\circ} \mathrm{C} / \mathrm{min}$ ，空気雲囲気下で測定を行った。

\subsection{4 動的機械分析(DMA)}

測定は，寸法約 $30 \times 3.0 \times 1.0 \mathrm{~mm}$ の試料を，動的粘弾 性測定装置(TA Instruments(侏製DMA2980)を用い，測 定温度範囲 - 130 300 ${ }^{\circ} \mathrm{C}$, 昇温速度 $5{ }^{\circ} \mathrm{C} / \mathrm{min}$, 周波数 1 $\mathrm{Hz}$ で, 強制非共振法により引張方向に $\pm 20.0 \mu \mathrm{m}$ の正弦 波振動歪を与えて行った.

\section{3. 結果および考察}

\subsection{CSの表面観察}

Figure 2 にCSの FE-SEM写真を示す．CSは，乾燥状態 では約 $100 \mu \mathrm{m}$ の粒子状に高次凝集しているが, 高倍率で 観察することで，凝集体を形成している基本的な粒子の径 は，その多くが $0.1 \mu \mathrm{m}$ 前後のサイズであることを確認し た。これより，基本粒子で見ればCSは充てん剤として用 いるのには十分な微粒子であると判断した.

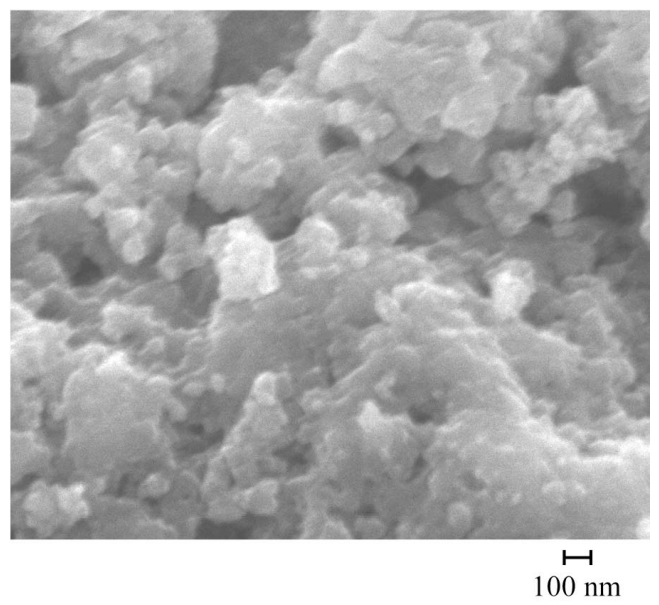

Figure 2 FE-SEM photograph of CS. 


\section{2 引張物性}

Table 1 に, 試料の応力-歪み曲線から得られた引張物性 值をそれぞれ示す. Figure 3 に示す初期モジュラスと添加 量の関係から，両者の添加によって，いずれも初期モジュ ラスはほぼ直線的に向上した。CB系と比較して CS 系の 傾きが大きく，用いた添加量範囲において CSの初期モジ ユラスに対する添加効果に優位性を認めた。一般的に，フ イラー充てんによるゴムの補強は，フィラー粒子表面とゴ 厶分子の相互作用，あるいは反応により拘束されたポリマ 一層が形成され，それにより，さらにゴムマトリクスの分 子運動性が影響を受けるためであると考えられる。これに は，表面性状の他に，粒子径，比表面積，CBではストラ クチャーの発達等が関係している。CSは，用いたCBに 比べて比表面積が小さく，一次粒子径もかなり大きいのに もかかわらず，CSの添加効果が大きく発現している．本 報で用いたCSは，詳細な分析はされていないがFigure 1 下図に示した様な欠陥構造を有するフラーレン類似物質の 集団として粒子が成り立っているとされており，CBとは 表面活性が異なると考える.

Figure 4 に，破断時の物性とそれぞれの添加量の関係を

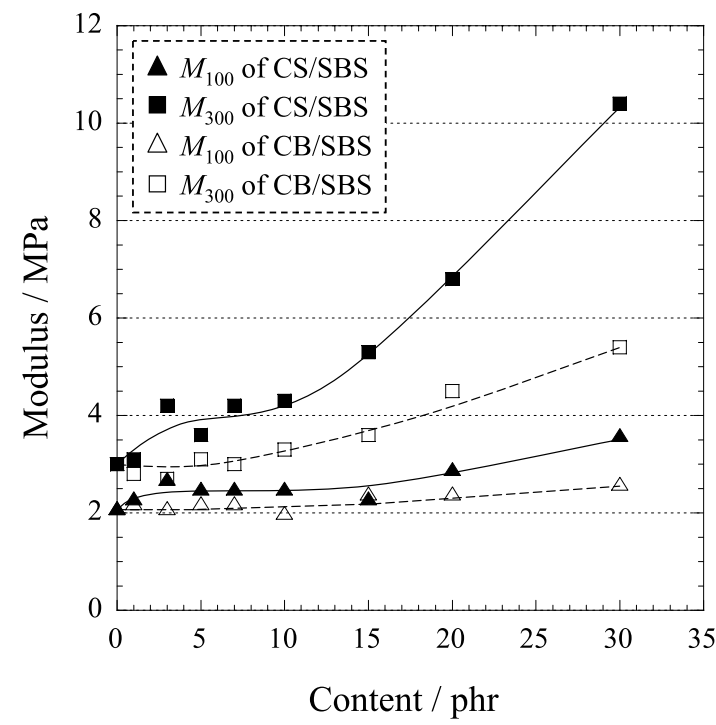

Figure 3 Relationships between tensile moduli of CS/SBS or $\mathrm{CB} / \mathrm{SBS}$ composites and content of filler.
示す. CSを1〜10 phr 添加することで， $E_{\mathrm{B}}$ を保持したま ま $T_{\mathrm{B}}$ が向上し，10 phr 添加で飽和值となり，それ以上の 添加量では低下する傾向を示した。

$E_{\mathrm{B}}$ は，10 phr 以上で添加量とともに低下した. CB系は, CS系と同様の傾向を示したが，20 phr 添加まで值が保持 され，CS系の方が大きく低下した。破断時の物性は，系 内の拘束されるポリマーの割合が過度に増加すると，外部 変形に対するエネルギー損失効果が低減し， $T_{\mathrm{B}}$ および $E_{\mathrm{B}}$ は低下することが知られている ${ }^{9)}$. CS系では，15 phrを 越える添加で $M_{300}$ が大きくなり， $E_{\mathrm{B}}$ が低下する．この $E_{\mathrm{B}}$ の低下の幅の相違は，フィラーーマトリクス界面の相互作 用の相違を示唆している.

CSを添加しても SBS元来のゴム弾性を損なうことなく， さらに初期モジュラスに対して効果があるため， CSの補 強用充てん剂としての可能性を示唆している．また，興味 深いことに，通常の補強用充てん剂によるゴム補強を考え た場合，その添加量は少なくとも本実験より多い量で議論 されることが多いが10)，CSにおいては，1〜10 phrの少 量添加において補強効果が得られることを認めた.

\subsection{DSC 測定}

CS/SBSのDSC 測定の結果を Figure 5 に示す．無添加

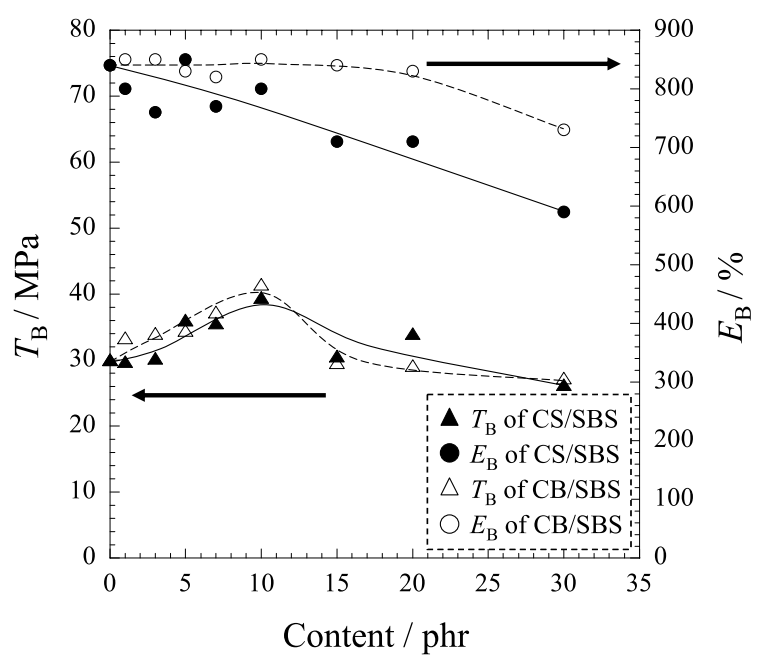

Figure 4 Relationships between tensile properties of CS/SBS or $\mathrm{CB} / \mathrm{SBS}$ composites and content of filler.

Table 1 The values of tensile properties of CS/SBS and CB/SBS composites.

\begin{tabular}{ccccccccc}
\hline \multicolumn{1}{c}{$\mathrm{CS} / \mathrm{SBS}$} \\
\hline Content / $\mathrm{phr}$ & $M_{100} / \mathrm{MPa}$ & $M_{300} / \mathrm{MPa}$ & $T_{\mathrm{B}} / \mathrm{MPa}$ & $E_{\mathrm{B}} / \%$ & $M_{100} / \mathrm{MPa}$ & $M_{300} / \mathrm{MPa}$ & $T_{\mathrm{B}} / \mathrm{MPa}$ & $E_{\mathrm{B}} / \%$ \\
\hline 0 & 2.1 & 3.0 & 30.1 & 840 & 2.1 & 3.0 & 30.1 & 840 \\
1 & 2.3 & 3.1 & 29.8 & 800 & 2.2 & 2.8 & 33.4 & 850 \\
3 & 2.7 & 4.2 & 30.3 & 760 & 2.1 & 2.7 & 34.1 & 850 \\
5 & 2.5 & 3.6 & 36.1 & 850 & 2.2 & 3.1 & 34.5 & 830 \\
7 & 2.5 & 4.2 & 35.6 & 770 & 2.2 & 3.0 & 37.3 & 820 \\
10 & 2.5 & 4.3 & 39.5 & 800 & 2.0 & 3.3 & 41.5 & 850 \\
15 & 2.3 & 5.3 & 30.6 & 710 & 2.4 & 3.6 & 29.6 & 840 \\
20 & 2.9 & 6.8 & 34.0 & 710 & 2.4 & 4.5 & 29.2 & 830 \\
30 & 3.6 & 10.4 & 26.3 & 590 & 2.6 & 5.4 & 27.3 & 730 \\
\hline
\end{tabular}




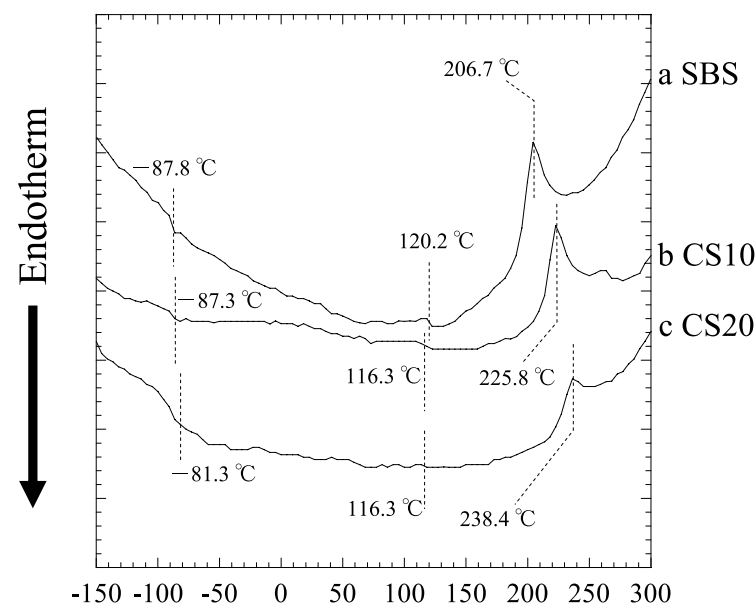

Temperature $/{ }^{\circ} \mathrm{C}$

Figure 5 DSC thermograms of (a) pure SBS, (b) CS10/SBS and (C) CS20/SBS.

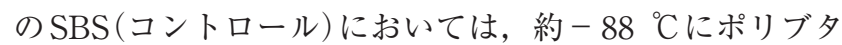
ジエン相抄よび約 $120{ }^{\circ} \mathrm{C}$ 付近にポリスチレン相のガラス転 移に起因する吸熱ショルダーを確認でき，その中点をガラ 入転移点 $\left(T_{\mathrm{g}}\right)$ とすると, CS の添加によって前者は少し高 温側に，後者は少し低温側に移動しながら，CS20では， いずれも認めにくくなった。スチレン含有率 $30 \mathrm{wt} \%$ の SBSに拈いては，スチレンドメインは球から棒状のミクロ 相分離構造を形成しているが，CSの添加によって相混合 が進行していると言える。また， $180{ }^{\circ} \mathrm{C}$ 超える高温側に

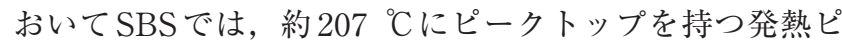
ークが確認でき，ポリブタジエンの自動酸化反応による酸 化劣化に起因すると考えられる ${ }^{11,12)}$. このピークが, CS の添加によって $10 \mathrm{phr}$ では $19{ }^{\circ} \mathrm{C}, 20 \mathrm{phr}$ では $32{ }^{\circ} \mathrm{C}$ それ ぞれ高温側にシフトし,さらにピーク面積も減少しており, 酸化反応が抑制されている.フラーレンには，本来，ラジ カル捕捉能があると言われているが13)，フラーレン製造 時の未抽出成分であるCSにおいても残存するフラーレン 類や，さらにFigure 19下図に示す様な欠損構造等によ り，類似した特徵が表れると考えた。また，SBSへのフラ ーレン類の添加によってUV光による架橋が容易に起こる ことも別の実験で認めており，CBとはかなり異なる挙動 を示すと考えられる。これらについては，後の論文で述べ たい.

\subsection{DMA}

DMAによる動的粘弾性の測定は，本報で取り扱う様な TPEの相構造解析，および複合化に伴う各相構造への影 響を分析するのに非常に有効な手段である。これは，例え ばDSC 測定では，融解やガラス転移等の大きな分子運動 の起点となる熱的現象は検知出来ても, 各現象間, もしく は融解以降の試料の状態を類推する情報を与えない。それ に対しDMAでは，任意の温度域における貯蔵弾性率 $\left(E^{\prime}\right)$

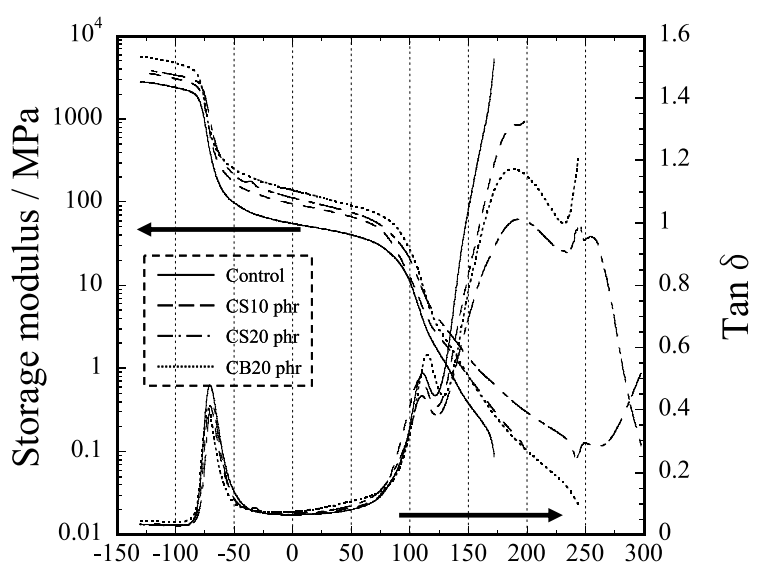

Temperature $/{ }^{\circ} \mathrm{C}$

Figure 6 Temperature dependence of dynamic mechanical properties for pure SBS, CS10, CS20 and CB20. The upper curves are storage moduli of the samples and the lower curves are mechanical loss tangents of those.

および損失弾性率 $(E)$ を測定するので，例えばゴム状域に おける $E^{\prime} へ の$ 影響, TPEの融解温度付近の $E^{\prime}$ への影響か ら, 対象とする添加物の各成分への相互作用の強さおよび 選択性を類推する情報となり得るからである。

Figure 6 にSBS，CS10，CS20 およびCB20のDMAの温 度分散結果を示す。

上方の曲線は貯蔵弾性率 $\left(E^{\prime}\right)$, 下方の曲線は損失正接 $(\tan \delta)$ の温度分散曲線をそれぞれ示している。CS/SBS 系のすべての試料の $E^{\prime} は, \mathrm{SBS}$ と同様にガラス化状態の

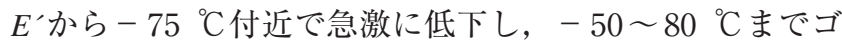
厶状平坦領域を示し, $100{ }^{\circ} \mathrm{C}$ 付近から流動域となり再び急 激に低下した。ゴム状平坦領域の $E^{\prime}$ は, 両者の添加によ って大きく増加しており，初期モジュラスの増加と一致す る. SBS の $\tan \delta$ 温度分散曲線は， $E^{\prime}$ の動きに相応した緩 和曲線を示し，二つのピークを確認した。これらの分散ピ 一クは， $-70{ }^{\circ} \mathrm{C}$ 付近㧍よび $110{ }^{\circ} \mathrm{C}$ 付近にあり，低温側を ポリブタジエン相のガラス転移に起因するピーク, 高温側 をポリスチレン相のガラス転移に起因するピークにそれぞ れ帰属し, そのピーク温度をガラス転移点 $\left(T_{\mathrm{g}}\right)$ とした。全 ての試料が，相分離構造を形成していることが分かる.

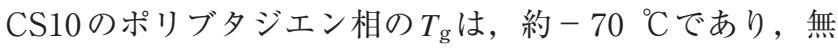
添加SBS と変わりないが，CS20においてはー $68.5{ }^{\circ} \mathrm{C}$ とな り，ピーク值が低下しながら若干高温側にシフトした。ま た，ポリスチレン相の $T_{\mathrm{g}}$ も，若干低温側にシフトしなが らピーク值が減少し，DSCの傾向と一致し，わずかに相 混合傾向となった。ゴム状平坦領域の $E^{\prime}$ は, 相分離が進 行するとスチレンドメインが補強作用を示し増大するが, 相混合が進行しているにもかかわらず，CSの添加によっ てE’が増大しており，CS界面との反応によるバウンドラ バーや架橋の生成が推察される.さらに, 無添加SBS の $E^{\prime}$ は，150 ${ }^{\circ} \mathrm{C}$ 超えると流動領域となり測定不可能になる 
が，CSの添加によってその流動領域が高温側に移動し， $20 \mathrm{phr}$ 添加では， $300{ }^{\circ} \mathrm{C}$ 近くまで保持した。 また， $E^{\prime} は$ は, $250{ }^{\circ} \mathrm{C}$ 超えると増加する傾向を示し, 昇温過程において 試料中で架橋反応が起こり, 網目構造を形成し, 測定後の 試料は樹脂状となった，DSCの結果と合わせて，200 ${ }^{\circ} \mathrm{C}$ 以 上で起こる酸化反応によって生じるラジカルを CSが捕捉 し, 架橋反応が進行すると考えられる。また， $120{ }^{\circ} \mathrm{C}$ 近傍 からポリスチレン相の流動に伴い $\tan \delta$ 值が上昇するが, 添加量とともに值が減少し， $20 \mathrm{phr}$ では新たなピークと なった.この様な架橋反応が， $120{ }^{\circ} \mathrm{C}$ での成形段階におい て若干進行し，ポリブタジエン相の流動が抑制され，ポリ スチレンドメインの分離，凝集が阻害されて緩和ピークの ピーク值および $T_{\mathrm{g}}$ が低下したと考えると，先のゴム状平 坦領域の $E^{\prime}$ の増加に対する推論を支持出来る。一方で, これら一連の架橋反応を示唆する現象は，CBを添加した 系では起こっていない.

さらに説明を加えると，粘弾性挙動と構造の関係に基づ くことで，系全体の補強効果を説明出来ると考えられる. すなわち，ポリブタジエン相の一部がCSのラジカル捕捉 の結果生じる結合等によって網目を形成し，分子鎖運動が 抑制され， $T_{\mathrm{g}}$ が高温側にシフトする。一方で，ポリスチ レン相は，無添加物中であればハードドメインを形成して 擬似架橋点となるが，形成したポリブタジエン相の網目お よびCSとの相互作用に影響され，ドメイン形成が阻害さ れることで, ポリスチレンに帰属したピーク值が減少する。 本来，ドメイン形成が十分でないならば，ゴム状領域の

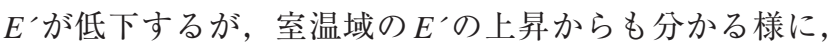
系全体の弾性率はCSの相互作用による相およびポリブ夕 ジエンの架橋の両者が寄与して増大している.この様に， 二種の作用の相乗効果によって SBSに対する補強効果が 明瞭に表れたと考えている。

\section{4. 結論}

フラーレン製造時の未抽出成分であるCSは，FE-SEM 観察より基本粒径 $100 \mathrm{~nm}$ 前後の凝集した粒子状であるこ とを認めた。次に, SBSへの添加によって得られたコンポ ジットの諸物性の測定から以下のことが分かった。

引張物性の結果から， 1〜10 phr の少量添加において も引張物性が向上することを認め, さらなる添加量におい て大きく向上し，カーボンブラックよりも添加効果が大き いことが明らかとなった。
DSC 測定の結果は，相分離構造を取るが，CSの添加に よって相混合傾向を示した。また，CSがポリマーの高温 下における酸化反応の開始を遅延し，発熱量を抑制する効 果があることを示した。さらに，DMAの結果からも，CS の添加によって流動領域後の高温域で $E^{\prime}$ が上昇し，架橋 が進行していると考えられるが，これらは，フラーレン類 の特徵であるラジカル捕捉能を示唆する結果であり, CS が機能的な補強性充てん剂としての可能性を持つことが明 らかとなった。

以上より，燃焼法によるフラーレン製造時の未抽出分で あるCSは，SBSに対して補強性および耐熱老化性付与の 機能を持つ材料として十分に応用展開可能であり，フラー レンにかかわる工業的な視点からも，価值のある知見が得 られた。

\section{References}

1) Kroto, H. W.: Nature, 329, 529 (1987)

2 ) Kroto, H. W.; Heath, J. R.; O’Brien, S. C.; Curl, R. F.; Smalley, R.E.: Nature, 318, 162 (1985)

3 ) Krätcher, W.; Lamb, L. D.; Fostiropoulos, K.; Huffman, D. R.: Nature, 347, 354 (1990)

4 ) Haufler, R. E.; Conceicao, J.; Chibante, L. P. F.; Chai, Y.; Byrne, N. E.; Flanagan, S.: J.Phys.Chem. 94, 8634 (1990)

5 ) Yeretzian C.; Hansen, K.; Whetten, R. L.; Diederich, F.: Nature, 359, 44 (1992)

6 ) Giacalone, F.; Martin, N.: Chem. Rev., 106, 5136 (2006)

7 ) Takakura, T.: Nippon Gomи Kyokaishi, 80, 179 (2007)

8 ) Murayama, H.: In "Nano Carbon Handbook", Endo, M., Iijima, S. Eds., NTS, Tokyo, p.540 (2007)

9 ) Fukumori, K.: In "Gomugijutu no Kiso (New ed.)", Nippon Gomu Kyokai Ed., Nippon Gomu Kyokai, Tokyo, Chapter 3 (1999)

10) Hirata, Y.: In "Gomugijutu no Kiso (New ed.)", Nippon Gomu Kyokai Ed., Nippon Gomu Kyokai, Tokyo, Chapter 7 (1999)

11) Wang, S.; Chang, J.; Tsiang, R. C.: Polym. Degrad. Stab., 52, 51 (1996)

12) Adam, C.; Lacoste, J;; Lemaire, J.: Polym. Degrad. Stab., 24, 185 (1989)

13) McEwen, C.N.; McKay, R.G.; Larsen, B.S.: J. Am. Chem. Soc., 114, $4412(1992)$

\section{日本語表記参考文献}

7 ）高倉剛：日本ゴム協会誌，80，179 (2007)

8 ）村山英樹：ナノカーボンハンドブック，遠藤守信，飯島澄男 監 修，エヌ・ティー・エス，東京，p.540 (2007)

9 ）福森健三：ゴム技術の基礎(新版)，日本ゴム協会編，日本ゴム 協会, 東京, 3 章 (1999)

10）平田靖：ゴム技術の基礎(新版)，日本ゴム協会編，日本ゴム協 会, 東京, 7 章 $(1999)$ 